\title{
(2) OPEN ACCESS \\ Multi-organ dysfunction as a presentation of calcium channel blocker intoxication
}

\author{
Abdul-Fatawu Osman, ${ }^{1}$ Rohan Madhu Prasad (1) , Shawn Marein, ${ }^{2}$ Corey O'Brien ${ }^{2}$
}

\begin{abstract}
Summary We report the case of a 73-year-old woman who intentionally ingested $400 \mathrm{mg}$ of amlodipine in a suicidal attempt who initially presented with hypotension which persisted despite aggressive therapy with fluid resuscitation, multiple pressor support, high-dose insulin therapy and calcium infusion. Her haemodynamic instability evolved to include bradycardia requiring atropine and transcutaneous pacing. Eventually she required salvage therapy with intravenous lipid emulsion (ILE) therapy . Despite all aggressive therapy, she developed multi-organ failure resulting in death. The literature on high-dose insulin euglycaemic therapy (HIET) and ILE therapy shows mixed results with some showing significant improvement in haemodynamic status. In our case, it had no significant positive impact on the outcome.
\end{abstract}

${ }^{1}$ Michigan State University, East Lansing, Michigan, USA ${ }^{2}$ Department of Pulmonary \& Critical care, Sparrow Health System, Lansing, Michigan, USA

Correspondence to Dr Abdul-Fatawu Osman; abdulfatawu01@gmail.com

Accepted 23 November 2021

Check for updates

(c) BMJ Publishing Group Limited 2022. Re-use permitted under CC BY-NC. No commercial re-use. See rights and permissions. Published by BMJ.

To cite: Osman A-F, Prasad RM, Marein S, et al. BMJ Case Rep

2022;15:e245711.

doi:10.1136/bcr-2021-

245711

\section{BACKGROUND}

Amlodipine is a dihydropyridine calcium channel blocker (CCB) which is commonly used in the management of essential hypertension and angina pectoris. Amlodipine has a low metabolic clearance, unlike other CCBs, with an advantage of using a once-daily dosage to maintain a near-constant plasma concentration. ${ }^{1}$

CCBs are widely prescribed cardiovascular medications with potentially lethal adverse effects even at mild overdoses. The current management of CCB overdose is mainly supportive with various measures including gastrointestinal decontamination, fluid resuscitation, intravenous calcium, vasopressor agents, atropine, high-dose insulin euglycaemic therapy (HIET) and cardiac pacing. ${ }^{2}$ Recently, intravenous lipid emulsion (ILE) therapy has emerged as a promising measure in management of CCB toxicity. ILE has been used previously in local anaesthetic toxicity, but recently, multiple case reports using ILE as an antidote for a wide range of lipophilic xenobiotic poisonings were published. ${ }^{2}$ ILE used in CCBs toxicity has demonstrated mixed results with some efficacy and a unique complication by preventing the use of renal replacement therapy. ${ }^{34}$

We review the literature and discuss the need for further research into CCB intoxication and its fatal consequences.

\section{CASE PRESENTATION}

A 73-year-old woman presented to the emergency department with altered mental status and agitation following an intentional overdose with 40 tablets of her $10 \mathrm{mg}$ amlodipine prescription. A friend contacted medics and raised concern for potential overdose with an estimated time of ingestion 12 hours prior to presentation. On initial presentation, the patient was hypotensive, but was otherwise not bradycardic and had an initial Glasgow Coma Scale (GCS) of 15.

Medical history was significant for noncompliance with medical follow-up and medication adherence, schizoaffective disorder with previous suicide attempts, poorly controlled hypertension and dextrocardia.

\section{INVESTIGATIONS}

Initial laboratory (lab) studies were concerning for acute kidney injury complicated by hyperkalaemia and metabolic acidosis, an elevated lactate of 8.4 $\mathrm{mmol} / \mathrm{L}$, mild elevation of transaminases and a Thyroid stimulating hormone (TSH) of $9.09 \mathrm{IU} / \mathrm{mL}$. Blood glucose was also elevated, above baseline, at $167 \mathrm{mg} / \mathrm{dL}$ (table 1). Otherwise, high-sensitivity troponins, brain natriuretic peptide, acetaminophen, salicylate levels and urine drug screens were normal.

A stat ECG showed junctional rhythm with atrioventricular dissociation and a regular rate (see figure 1). A two-dimensional transthoracic echocardiogram revealed normal size left ventricle, ejection fraction of $55 \%-60 \%$, moderate mitral regurgitation and an elevated mean left atrial pressure. A chest X-ray (CXR) showed dextrocardia with no evidence of cardiomegaly, evidence of vascular congestion nor focal infiltrates.

\section{DIFFERENTIAL DIAGNOSIS}

Considering that collateral history had already provided a known toxic ingestion and lab work revealed acute metabolic disturbances, the remaining primary differential diagnosis included possible coingestion of other pharmaceutical agents or illicit substances, an acute psychotic episode, infection and less likely hepatic encephalopathy or myxoedema.

\section{TREATMENT}

The patient presented with vasoplegic shock complicated by multi-organ dysfunction that was unresponsive to fluid resuscitation with crystalloids and close monitoring. Therefore, after 5 hours from presentation, vasopressor support was initiated in the form of a norepinephrine drip. Unfortunately, the patient became minimally responsive with a GCS of $<8$; therefore, the decision was made to intubate and mechanically ventilate the patient for airway protection. She was transferred to the intensive care unit where high-dose insulin therapy, calcium infusion, volume resuscitation and up-titration of vasopressors were executed. A sodium bicarbonate 
Table 1 Laboratory findings on presentation compared with the laboratory finding on the day of mortality

\begin{tabular}{lcc}
\hline Labs & Day 1 (on presentation) & $\begin{array}{l}\text { Day } 3 \text { (on the day patient } \\
\text { expired) }\end{array}$ \\
\hline BUN, serum & $35 \mathrm{mg} / \mathrm{dL}$ & $38 \mathrm{mg} / \mathrm{dL}$ \\
\hline Creatinine, serum & $2.59 \mathrm{mg} / \mathrm{dL}$ & $2.25 \mathrm{mg} / \mathrm{dL}$ \\
\hline eGFR & $15 \mathrm{~mL} / \mathrm{min}$ & $21 \mathrm{~mL} / \mathrm{min}$ \\
\hline Potassium, serum & $5.2 \mathrm{meq} / \mathrm{L}$ & $4.1 \mathrm{meq} / \mathrm{L}$ \\
\hline Bicarbonate, serum & $19 \mathrm{mmol} / \mathrm{L}$ & $20 \mathrm{mmol} / \mathrm{L}$ \\
\hline Lactate, serum & $8.4 \mathrm{mmol} / \mathrm{L}$ & $3.2 \mathrm{mmol} / \mathrm{L}$ \\
\hline Glucose, serum & $167 \mathrm{mg} / \mathrm{dL}$ & $124 \mathrm{mg} / \mathrm{dL}$ \\
\hline Anion gap, serum & 19 & 5 \\
\hline AST & $65 \mathrm{U} / \mathrm{L}$ & $227 \mathrm{U} / \mathrm{L}$ \\
\hline ALT & $67 \mathrm{U} / \mathrm{L}$ & $248 \mathrm{U} / \mathrm{L}$ \\
Alkaline phosphatase & $50 \mathrm{U} / \mathrm{L}$ & $51 \mathrm{U} / \mathrm{L}$ \\
\hline
\end{tabular}

ALT, Alanine transaminase; AST, Aspartate transaminase; BUN, Blood urea nitrogen; eGRF, Estimated Glomerular Filtration Rate.

drip was also added due to worsening metabolic acidosis. No significant improvement was made in terms of haemodynamic stability and the patient's rhythm ultimately became profoundly bradycardic requiring atropine and transcutaneous pacing. In consultation with local poison control, the decision was made to attempt ILE therapy. Despite these interventions, hypotension persisted despite four vasopressors, including norepinephrine, epinephrine, vasopressin and phenylephrine, were ultimately required. Fever and leucocytosis developed, thus empiric broad spectrum antibiotic coverage with linezolid and cefepime was started. Urine output diminished, vascular congestion developed and the inability to oxygenate occurred despite maximal ventilator settings. Continuous renal replacement therapy was attempted, but the patient's blood pressure could not tolerate any fluid removal and she became even more unstable. Family members ultimately decided to de-escalate the level of care and shortly thereafter the patient passed away.

\section{OUTCOME AND FOLLOW-UP}

Unfortunately, the patient died.

\section{DISCUSSION}

Amlodipine is a dihydropyridine CCB, which is widely available and has a variety of indicated usages. It is highly protein bound, has a large volume of distribution and a half-life of 30-50 hours. ${ }^{5}$ Dihydropyridines preferentially block the L-type calcium

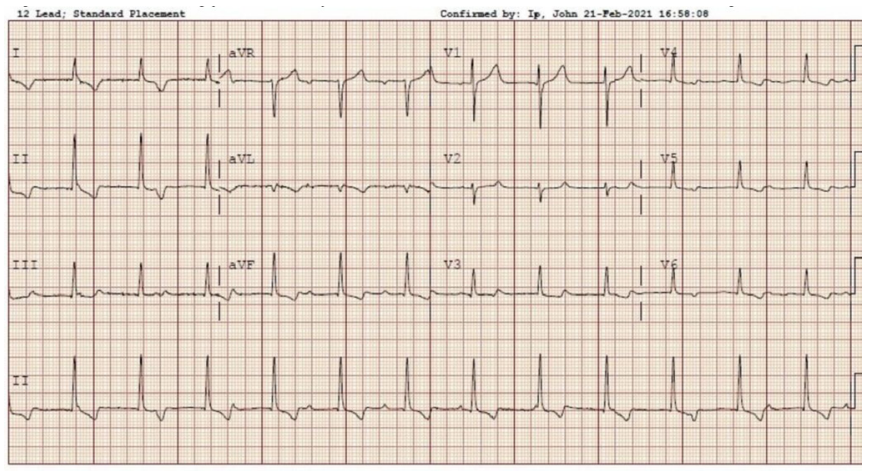

Figure 1 ECG on presentation to the emergency department showing junctional rhythm with atrioventricular dissociation and a regular rate (see figure file). channels in the peripheral vasculature. At standard doses, these medications are potent vasodilators, but have little negative inotropic or chronotropic effect. In comparison, standard doses of the non-dihydropyridines, verapamil and diltiazem, selectively block L-type calcium channels in the myocardium leading to reduced cardiac conduction and contractility with weak vasodilatory effects.

Dihydropyridine intoxication initially results in arterial vasodilation and reflex tachycardia, but as doses increase receptor selectivity is lost. At toxic levels, dihydropyridines may negatively affect the myocardium and cardiac conduction system leading to decreased inotropy, bradycardia and heart block. Amlodipine toxicity induced-atrioventricular conduction disturbances range from prolonged PR intervals to complete atrioventricular dissociation with accelerated junctional rhythm. Additionally, CCBs selectively dilate the afferent branch of capillary networks which, in states of preserved or increased blood flow, may lead to oedema formation including non-cardiogenic pulmonary oedema (NCPE). A cohort study, by Erik et al, investigated amlodipine poisoning and found an incidence of $47 \%$ of NCPE of the whole cohort and $64 \%$ who did not go on to develop complete haemodynamic collapse. ${ }^{6}$

Consensus guidelines for amlodipine intoxication have been established and these include calcium infusion for all, preferential use of norepinephrine in the presence of vasodilatory shock, and HIET in the presence of vasodilatory shock. There is no formal recommendation regarding fluid repletion due to limited evaluation, but nonetheless fluid administration is considered first line therapy. Intralipid emulsion therapy, inotropes, transcutaneous pacing, atropine and additional vasopressors are more or less considered salvage therapies with weak levels of evidence and low strength of recommendations. ${ }^{7}$

Management for CCB toxicity is evolving although slowly. Data are limited and high-quality studies are challenging, if not impossible, to perform. The therapy that is gaining the most support is HIET. In particular, HIET has shown some benefit in scenarios with proven myocardial dysfunction. ${ }^{8}$ In poor haemodynamic conditions, cardiac myocytes transition from oxidising free-fatty acids, as a preferred energy source, to carbohydrates. CCBs also affect channels in pancreatic islet cells which lead to decreased insulin secretion, associated hyperglycaemic and reduced myocardial glucose utilisation hence impairing inotropy. ${ }^{9}$ HIET theoretically overcomes hypoinsulinaemia and insulin resistance, in cardiac myocytes, by improving glucose uptake, myocardial utilisation of glucose and thus restores the impaired cellular energy platform which leads to haemodynamic deterioration. $^{8}$ 10-13

HIET protocol includes an initial insulin bolus of 1 units $/ \mathrm{kg}$ followed by insulin infusion of 0.5 units $/ \mathrm{kg} /$ hour along with $10 \%$ dextrose in half-normal saline. Blood glucose is checked at least once every $30 \mathrm{~min}$ and hypertonic glucose may be required to maintain blood glucose in the upper normal range. Additionally, supplemental potassium may be required to prevent severe hypokalaemia. ${ }^{14}$

Since the mid-1980s, new prescriptions for CCBs have increased exponentially. ${ }^{15} \mathrm{CCBs}$ are the leading cause of cardiovascular drug overdose and are responsible for $48 \%$ of deaths related to cardiovascular drug exposure. ${ }^{16}$ The potential for toxicity with CCBs is substantial and frankly underappreciated. Our case shows a patient who was found to have vasoplegic shock, multi-organ dysfunction and atrioventricular dissociation, related to amlodipine overdose who ultimately passed away. This illustrates how important it is to understand the underlying pathophysiology and supported therapies as well 
as to continue pursuit of effective treatment strategies as this presentation becomes more and more commonplace.

\section{Learning points}

- Patient presenting with calcium channel blockers (CCBs) (amlodipine) intoxication can be presented with multi-organ dysfunction and will immediately need to be managed in the intensive care unit.

- Monitoring for anticipated complications and targeted management of these complications can be lifesaving.

- Early initiation of high-dose insulin euglycaemic therapy has been proven effective in some cases of CCBs toxicity and should be considered.

Contributors AFO: obtained consent, wrote abstract, introduction, case presentation, discussion, conducted literature review and edited the final manuscript. Made revision. RMP: wrote discussion, conducted literature review, edited the final manuscript and made revision. SM: Assisted in writing case narative, discussion, literature review and edited the final draft. CO: Assisted in all phases and helped edit the final manuscript.

Funding The authors have not declared a specific grant for this research from any funding agency in the public, commercial or not-for-profit sectors.

Competing interests None declared.

Patient consent for publication Consent obtained from next of kin.

Provenance and peer review Not commissioned; externally peer reviewed.

Open access This is an open access article distributed in accordance with the Creative Commons Attribution Non Commercial (CC BY-NC 4.0) license, which permits others to distribute, remix, adapt, build upon this work non-commercially, and license their derivative works on different terms, provided the original work is properly cited and the use is non-commercial. See: http://creativecommons.org/ licenses/by-nc/4.0/.

Case reports provide a valuable learning resource for the scientific community and can indicate areas of interest for future research. They should not be used in isolation to guide treatment choices or public health policy.
ORCID iD

Rohan Madhu Prasad http://orcid.org/0000-0001-8873-5594

\section{REFERENCES}

1 Abernethy DR, Schwartz JB. Calcium-antagonist drugs. N Engl J Med 1999:341:1447-57.

2 Graudins A, Lee HM, Druda D. Calcium channel antagonist and beta-blocker overdose: antidotes and adjunct therapies. Br J Clin Pharmacol 2016:81:453-61.

3 Karbek Akarca F, Akceylan E, Kıyan S. Treatment of amlodipine intoxication with intravenous lipid emulsion therapy: a case report and review of the literature. Cardiovasc Toxicol 2017; 17:482-6.

4 Rodríguez B, Wilhelm A, Kokko KE. Lipid emulsion use precluding renal replacement therapy. J Emerg Med 2014;47:635-7.

5 Donnelly R, Meredith PA, Miller SH, et al. Pharmacodynamic modeling of the antihypertensive response to amlodipine. Clin Pharmacol Ther 1993;54:303-10.

6 Lindeman E, Ålebring J, Johansson A, et al. The unknown known: non-cardiogenic pulmonary edema in amlodipine poisoning, a cohort study. Clin Toxicol 2020;58:1042-9.

7 St-Onge M, Anseeuw K, Cantrell FL, et al. Experts consensus recommendations for the management of calcium channel blocker poisoning in adults. Crit Care Med 2017:45:e306-15

8 Patel NP, Pugh ME, Goldberg S, et al. Hyperinsulinemic euglycemia therapy for verapamil poisoning: a review. Am J Crit Care 2007:16:498-503.

9 Kline JA, Raymond RM, Schroeder JD, et al. The diabetogenic effects of acute verapamil poisoning. Toxicol App/ Pharmacol 1997;145:357-62.

10 Kerns W. Management of beta-adrenergic blocker and calcium channel antagonist toxicity. Emerg Med Clin North Am 2007:25:309-31.

11 Das UN. Insulin: an endogenous cardioprotector. Curr Opin Crit Care 2003;9:375-83.

12 Proano L, Chiang WK, Wang RY. Calcium channel blocker overdose. Am J Emerg Med 1995:13:444-50.

13 Kumar K, Biyyam M, Bajantri B, et al. Critical management of severe hypotension caused by amlodipine toxicity managed with Hyperinsulinemia/Euglycemia therapy supplemented with calcium gluconate, intravenous glucagon and other vasopressor support: review of literature. Cardiol Res 2018;9:46-9.

14 Boyer EW, Duic PA, Evans A. Hyperinsulinemia/euglycemia therapy for calcium channe blocker poisoning. Pediatr Emerg Care 2002;18:36-7.

15 Epstein M. Calcium antagonists: still appropriate as first line antihypertensive agents. Am J Hypertens 1996:9:110-21.

16 DeWitt CR, Waksman JC. Pharmacology, pathophysiology and management of calcium channel blocker and beta-blocker toxicity. Toxicol Rev 2004;23:223-38.

Copyright 2021 BMJ Publishing Group. All rights reserved. For permission to reuse any of this content visit

https://www.bmj.com/company/products-services/rights-and-licensing/permissions/

BMJ Case Report Fellows may re-use this article for personal use and teaching without any further permission.

Become a Fellow of BMJ Case Reports today and you can:

- Submit as many cases as you like

- Enjoy fast sympathetic peer review and rapid publication of accepted articles

- Access all the published articles

Re-use any of the published material for personal use and teaching without further permission

Customer Service

If you have any further queries about your subscription, please contact our customer services team on +44 (0) 2071111105 or via email at support@bmj.com.

Visit casereports.bmi.com for more articles like this and to become a Fellow 